\title{
Trump, Litigation, and Threats: From Queens to the World Stage
}

\author{
Stuart S. Malawer*
}

Donald Trump's methods of operating and conducting national security and foreign policy are exactly the same as they would be if he was engaged in real estate transactions and deals. To Donald Trump, trade policy, foreign policy, and national security policy are transactions and zero-sum games. My thesis is straightforward: One can draw a straight line from Donald Trump's ruthless mode of operating in the contentious world of New York real estate to his operations on the world stage today. From Queens to the world stage, there is a straight line from using threats and litigation to avoid commercial and contractual obligations to using threats and litigation in conducting the US foreign and trade policy. Especially as to policies pertaining to the World Trade Organization and the US-China trade relations. His weaponization of tariffs and economic sanctions is now being wielded as a principal tool of the US foreign policy for the first time since the early 1930 s.

Keywords: Trade Wars, Tariff Wars, Economic Sanctions, Trump's Real Estate, Trump's Domestic Litigation, Foreign Policy by Tariff Threats, National Security, $\$ 232$ National Security Tariffs, WTO, Dispute Resolution System

* Distinguished Service Professor of Law and International Trade at George Mason's University's Schar School of Policy and Government. J.D. (Cornell), M.A./Ph.D. (UPenn), Diploma (Hague Academy of International Law). Additional legal studies at Harvard Law School and Oxford University (St. Peter's College). He is the author of WTO Law, Litigation \& Policy (Hein 2007), U.S. National Security Law (Hein 2009) and Global Trade and International LaW (Hein 2012). Dr. Malawer is a member of the bars of the State of New York, the Commonwealth of Virginia and of the United States Court of International Trade. He is a recent gubernatorial appointee to the new Advisory Committee on International Trade (Virginia Economic Development Partnership). Dr. Malawer has been a delegate on various Virginia gubernatorial trade missions to Asia. He is a former Chairman of the International Practice Section of the Virginia State Bar. The author may be contacted at: StuartMalawer@msn.com; http://www.GlobalTradeRelations. net; http://www.US-Global-Law.net/Address: 3351 Fairfax Dr., MS 3B1, Arlington, Virginia 22201 USA. All the websites cited in this paper were last visited on February 10, 2020. The paper was completed as of that date. 


\section{Introduction}

Donald Trump was born and raised in Queens, New York, one of the five boroughs of New York City, with a current population of more than two million. His formative years were during the 1960s and 1970s. Born in Queens at about the same time as Trump, I lived within a mile or two of Donald Trump during many of those formative years.

From the outset of Donald Trump's real estate career, and then his public one, I understood his ruthless approach to conducting transactions, always relying upon bullying and threats in negotiations and utilizing meritless litigation.

Very simply, his views were fostered by his contentious real estate career, which was conducted through myriad partnerships initially funded and organized by his father, Fred Trump. Multimillion dollar portfolios in real estate are often controlled by a small number of people operating through family-controlled or mom-and-pop operations. In this case, the Trump Organization, which Donald Trump organized in 1976 when he began to emerge from his father's coattails.

Unfortunately, the real estate industry is marked by extremely contentious relations. Threats and litigation are hallmarks of this hypercompetitive industry, in which millions, if not billions, of dollars are at stake. Real estate and partnership litigation are well-known to be extraordinarily brutal because so much money and so many egos are involved. Donald Trump is a product of this environment, even more so than most real estate investors.

Donald Trump's methods of operating and conducting national security and foreign policy are exactly the same as they would be if he was engaged in real estate transactions and deals. To Donald Trump, trade policy, foreign policy, and national security policy are transactions and zero-sum games. He makes decisions with only a few people around him, including his family members, using threats and litigation to get his way.

My thesis is straightforward: One can draw a straight line from Donald Trump's ruthless mode of operating in the contentious world of New York real estate to his operations on the world stage today.

From Queens to the world stage, there is a straight line from using threats and litigation to avoid commercial and contractual obligations to using threats and litigation in conducting the US foreign and trade policy. Especially as to policies 
pertaining to the World Trade Organization ("WTO") and the US-China trade relations. His weaponization of tariffs and economic sanctions is now being wielded as a principal tool of the US foreign policy for the first time since the early 1930s.

President Trump's ruthless approach has been employed in a range of multilateral trade relations (such as the Trans-Pacific Partnership and the USMexico-Canada Agreement), and bilateral agreements with Korea and Japan. It has also gone beyond bilateral trade disputes by attacking the legitimacy of the WTO's judicial system and, indeed, the WTO itself. Beyond trade, this caustic approach has been applied to a range of issues in American foreign policy. For example, the withdrawal by the US from a broad list of international agreements and institutions, including the Iran nuclear deal, UNESCO, and the Paris Climate Accord.

\section{Donald Trump's World of Litigation-Yesterday and Today}

\section{A. Before Becoming President}

In the recent book entitled, "Plaintiff in Chief-A Portrait of Donald Trump iN 3,500 Lawsuits (2019)" by James D. Zirin, a trial lawyer and federal prosecutor in New York for more than 50 years, ${ }^{1}$ the author examines the lengthy history of Donald Trump in private litigation and concludes Donald Trump's political worldview was molded in the courtroom. "Trump sees law not as a system of rules to be obeyed and ethical ideals to be respected, but as a weapon to be used against his adversaries or a hurdle to be sidestepped when it gets in his way. $\mathrm{He}$ has weaponized the justice system throughout his career, and he has continued to use these backhanded tactics." Zirin concludes his extensive investigative study of Donald Trump's history of private litigation by stating, "[T]he past is prologue, and his 3,500 or more lawsuits furnished an accurate prediction as to how he would react in office. He has not disappointed, and it has not been a pretty picture."3

In an earlier and perhaps even more extensive analysis, USA TODAY in 2016 examined 4,095 cases involving Donald Trump stretching back to the 
1970s. ${ }^{4}$ For the first time, this study categorized the extensive number of cases involving Trump in federal, state, and county courts throughout the US. These cases involved trademarks, casinos, contract disputes, employment, golf clubs, government and tax issues, media and defamation, personal injury, and real estate. The largest numbers of cases were related to casinos, personal injury, and real estate. $^{5}$

Some of the very earliest cases filed against Fred and Donald Trump involved refusals to rent to blacks in Trump properties in the 1960s and 1970s. The US Department of Justice sued the father and son in $1973^{6}$ in a case the family fought tooth and nail. A consent decree was entered against the Trumps. James Zirin concluded, "A life of litigation was the building block for Trump's approach to public office." Trump's politics of grievance and resentment today has at its foundation grievances nurtured from his earliest days in real estate. When Manhattan real estate families viewed him as being from the outer-borough of Queens and not one of them.

\section{B. Since Becoming President}

After examining the cases that have involved President Trump since his coming into office, New York Times reporter Peter Baker stated: "Even as President Trump tries to fend off the ultimate threat of impeachment for high crimes and misdemeanors, he and his team are waging simultaneous legal battles on a wide array of fronts, facing perhaps more significant challenges with more consequences to his presidency than any modern occupant of the Oval Office has confronted at one time." ${ }^{\circ}$ These cases have entailed defamation lawsuits and disputes over turning over his tax returns, among a broad range of other actions, including immigration and the environment.

President Trump is being sued for exceeding his executive authority and for personal matters. As president, he seems to have relished the idea that he or his administration would be a defendant in cases that starkly diverge from prior administration policies. In the context of trade, for example, his administration has been sued by the US steel importers for improperly imposing tariffs under national security legislation (Section 232 of the Trade Expansion Act of 1974). ${ }^{10}$ Most recently, a newer case by Turkey in the United States Court of International Trade may have historically significant implications. The recent preliminary 
decision in this case, to deny the government's motion to dismiss, has the potential to change the landscape surrounding the laws for trade remedies under a national security rationale. ${ }^{11}$ Baker concluded: "Mr. Trump has always had a taste for legal combat ... He sued contractors and debtors as well as Bill Maher and Miss Pennsylvania." $"$ "2

As the impeachment scenario unfolds, President Trump is confronting a broad range of legal and investigatory proceedings. ${ }^{13}$ For example, House committees are seeking to gain access to Trump's tax and business records, and New York (Manhattan) prosecutors have also subpoenaed his tax returns. Lawsuits were filed concerning the emolument clause. A recent analysis of Trump's legal troubles concluded: "Trump, already facing an impeachment trial while campaigning for a second term in office, is saddled with an unprecedented onslaught of investigations and lawsuits, many alleging he is violating the law by accepting money from U.S. taxpayers and foreign governments." ${ }^{14}$

A former federal judge, Brooke Masters, recently pointed out: "Never in history have the federal courts been called upon - and been eager to - decide so many disputes over presidential power, or for that matter, separation of powers between the president and congress." ${ }^{, 15}$ Masters continued: "Despite the conservative majority in the Supreme Court it is not clear how these battles will turn out. The historical precedents are not comforting for the president." ${ }^{, 16}$ Indeed, the General Accounting Office ("GAO") recently declared President Trump's withholding of military aid to Ukraine a violation of federal law (Impoundment Control Act). ${ }^{17}$ The GAO report stated: "Faithful execution of the law does not permit the President to substitute his own policy priorities for those that Congress has enacted into law." 18

\section{Trump's Tariffs and Economic Sanctions}

Tariffs and economic sanctions have become the central tools of President Trump's trade policy in particular and foreign policy in general. A recent article in the Wall Street Journal stated: "The Trump administration is wielding U.S. economic might - through tariffs, sanctions and other measures - as a geopolitical weapon for battles with adversaries and allies alike."19 Trump's slogan "America 
First" was a policy espoused by American isolationist in the 1930s and by the German-American Bund, as a central plank in its pro-Nazi policies.

Within the US, the president's use of tariffs has come under legal attack. For example, the Court of International Trade in New York, in several cases, is considering the validity of the administration's use of Section 232 of the Trade Act of 1974 as a basis for imposing steel tariffs on various countries. ${ }^{20}$ Indeed, the US Department of Justice has just recently become involved in the Section 232 issue, making the case even more politicized. The Justice Department backed up the president for not following a new statutory provision claiming that provision violates executive privilege. ${ }^{21}$ This provision requires publication of a Section 232 report by the US Department of Commerce as to proposed tariffs on auto exports from Europe. Paul Krugman, a well-known international economist, recently exclaimed: "Trump's scofflaw behavior with regard to auto tariffs is part of a broader pattern of abuse of power and contempt for the rule of law." ${ }^{22}$

The Trump administration has been employing tariffs and economic sanctions more vigorously than any other administration as the principal tools of its foreign policy. You might even call Trump's stance in this regard foreign policy by tariff threats.

Perhaps the best example of this policy is the recent phase one agreement pausing the trade war between the US and China. Despite cries of mercantilism and managed trade, the agreement keeps in place a huge number of tariffs on Chinese imports and an additional number that may be applied by the administration if there is a lack of cooperation by China. Indeed, the Trump administration has imposed newer duties on downstream steel and aluminum products such as nails and cables. Illustrating the economic concept of "cascading tariffs." An even newer case in the United States Court of International Trade has challenged this as being an unconstitutional delegation of legislative authority by congress to the president. Additional Section 232 cases are expected to be filed by downstream steel users of derivative products in the Court of International Trade challenging the newer tariff increases. So the threats by Trump continue to this day. Two Washington Post reporters have noted: “Trump's maximalist approach to diplomacy has become a hallmark of his administration's foreign policy.",23

What is even more startling, but not as well publicized, is the way this new agreement does an end run around traditional dispute settlement. A well-known 
commentator, Bob Davis, recently determined: "The phase-one deal between the U.S. and China could upend the way trade disputes are settled globally." ${ }^{24}$ The deal rejects the use of an independent tribunal and substitutes three rounds of negotiations that will then allow unilateral sanctions to be imposed by the US if there is no resolution of the trade dispute.

This unorthodox provision reflects the administration's obsession with doing away with the Appellate Body of the WTO, the entire WTO dispute resolution system, as well as independent dispute panels elsewhere, viewing them as a violation of the US sovereignty.

Bob Davis also concluded: "The Trump administration has been fiercely critical ... believing that panels suck away U.S. sovereignty and don't follow trade law. The administration has crippled the WTO dispute-resolution system by not approving new judges." ${ }^{25}$ The Council on Foreign Relations in a recent publication stated: "U.S. President Donald J. Trump has long criticized trade dispute resolution panels as unfair and ineffective ... While some critics says dispute panels undermine national sovereignty, proponents argue they offer muchneeded protections that boost confidence in global investment and trade wars." ${ }^{26}$

It should be noted there are a number of concerns relating to the validity of the US-China trade agreement in the context of the WTO rules. For example, does the agreement violate the most-favored-nation principle as to new tariff levels or violate GATT Article XXIV, which allows only custom union and free trade agreements as an exception to the most-favored-nation principle? The European Union trade commissioner Phil Hogan was quoted as saying: "We haven't analyzed the document in detail, but we will. And if there's a WTO compliance issue, of course we will take a case [to the WTO]. ${ }^{, 27}$

\section{Trump Administration in the WTO}

My analysis of the Trump administration's litigation strategy in the WTO is a bit different from my assessment of President Trump's domestic litigation strategy.

In contrast to his personal history of often filing multiple lawsuits without merit, the Trump administration has refrained from such filings in the WTO. Instead, the US has continued to file disputes with merit in the WTO. For example, 
in 2018, it filed eight cases and pursued three earlier cases. The recent 2019 USTR Trade Policy Agenda stated: "In 2018, the United States continued to be one of the most active participants in the WTO dispute settlement process. ${ }^{28}$ This is a bit of an overstatement. It is also somewhat at odds with the US's public attacks on the dispute resolution system, the Appellate Body, and the WTO. To further illustrate this inconsistency, the US has recently appealed a panel decision in favor of India over the US steel duties, even though the Appellate Body is not functioning because of a lack of judges due to the US actions. ${ }^{29}$

However, much more seriously, President Trump has more broadly aimed at destroying the dispute resolution system, taking particular aim at the Appellate Body. This scheme, in the even larger context of attacking the entire WTO system and the rules-based global trading system, makes no sense. Analysts have unanimously concluded that the US wins more WTO cases than China in the US-China trade disputes, ${ }^{30}$ and the WTO usually sides with the US in these disputes. ${ }^{31}$ This mirrors my earlier conclusions concerning the WTO litigation. ${ }^{32}$ However, the administration's policy today is starkly in-line with Trump's earlier behavior as a real estate operator, attacking publicly courts and institutions with which he has found himself at odds, no matter what.

\section{Note on Trump's Worldview}

What accounts for President Trump's worldview? First, as I discussed, is his outlook that threats, bullying and unilateral actions are the way to go. These views were solidified in his opposition to Japan's aggressive role in New York real estate in the 1980s. I simply do not believe there is any coherent strategy behind any of his substantive actions. Indeed, these actions have often caused increased tensions with many countries. President Trump, harking back to his real estate days, views all relations as transactional. He views them as zero-sum games: you either win or lose. "But to the extent there is a Trump doctrine, it amounts to this: Use tariffs, sanctions, and other means of economic pressure to compel U.S. adversaries - and, as often, allies - to accede to White House demands. ${ }^{, 33}$ This perspective continued at the recent Davos conference in January 2020, where President Trump again threatened Europeans with new tariffs on auto exports to the US. ${ }^{34}$ 
Before coming to the White House, President Trump had no military or government experience, having immersed himself in the insular world of New York real estate. While New York City is a great world capital and very demographically diverse, neither quality is true for the world of the real estate developers in Manhattan. Therefore, the president came to the office with no real understanding of diplomacy or the world. He viewed tariffs and trade relations as essentially bilateral transactions, by which he could maximize the US economic power to get his way. ${ }^{35}$

So far, this has happened, but to a limited extent. Trump's policies have caused significant injury to the US farmers and the manufacturing sector. Indeed, in December 2019, the Federal Reserve Board released a study on tariffs and manufacturing and concluded the benefit from tariff protections "is offset by larger negative effects from rising input costs and retaliatory tariffs." ${ }^{36}$ Commentators reviewing this report further observed, "American businesses and consumers, not China, are bearing the financial brunt of President Trump's trade war.",37

\section{Conclusion}

From his days owning and managing middle-class apartments as a real estate operator in Queens, New York, to his time in the White House, Donald Trump has relied upon threats and bullying and today has grossly abused the domestic and international legal systems.

On January 15, 2020, the day President Trump signed the limited trade agreement with China, which were a result of his tariff and threats, the articles of impeachment were delivered to the Senate to commence his trial on two impeachment charges. The two articles of impeachment are for abuse of presidential authority and obstruction of Congress. To me, these acts are a direct byproduct of his general disregard for legal rules and institutions going back to his earliest real estate days in the 1960s and 1970s.

Trump's disregard for international laws, institutions, alliances, and agreements is extremely worrisome. He possesses a truly generalized hatred for all rules that is mirrored in many ways, his management of the Trump Organization and his career as a real estate professional. 
Trump's disregard of international rules is clearly seen in his attacks on a broad range of treaties and institutions. I would argue none is more delusional than his frontal attacks on the WTO, the dispute resolution system and the Appellate Body. These were devised primarily by the US. They are the central pillars of the global trading system today. They help establish and litigate global trade rules. The boy from Queens is now causing havoc in Geneva, Brussels, Tokyo, Seoul, and almost all other world capitals.

Of course, President Trump's abuse of the US trade legislation (in his tariff and trade wars), his pattern of bullying and threats, his disregard of domestic law in a broad range of domestic matters, and his dealings with Congress are related stories. His rejection of international rules and institutions has its roots in his shameless attacks on domestic US law and institutions. All of these affronts are directly related to Trump's days in Queens as a landlord sued by many, including the US Department of Justice. These affronts continue today and are getting worse.

President Trump's story has yet to play out on either the national or the international stage. His impeachment is already history. The 2020 presidential election is looming. We all wait to see the outcome.

\section{REFERENCES}

1. J. Zirin, Plaintiff in Chief-A Portrait of Donald Trump in 3,500 Lawsuits (2019).

2. Id. at 2 .

3. Id. at 237. The Pulitzer Prize winner Michael D'Antonio summarizes his prelection treatise of Donald Trump by stating, "Menace has long been a defining characteristic of the Trump modus operandi.” See M. D’Antonio, The Truth About Trump 2 (2016).

4. J. Kelly \& N. Penzenstadler, How USA TODAY NETWORK is Tracking Trump Court Files, USA Today, June 1, 2016, available at https://www.usatoday.com/story/news/politics/ elections/2016/06/01/how-usa-today-network-gathered-trump-court-files/85043410.

5. Id.

6. J. Mahler \& S. Eder, 'No Vacancies' for Blacks: How Donald Trump Got His Start, and Was First Accused of Bias, N. Y. Times, Aug. 27, 2016, available at https://www.nytimes. com/2016/08/28/us/politics/donald-trump-housing-race.html.

7. ZIRIN, supra note 1 , at xvi. 
8. P. Baker, Trump is Fighting So Many Legal Battles, It's Hard to Keep Track, N. Y. Times, Nov. 6, 2019, available at https://www.nytimes.com/2019/11/06/us/politics/donald-trumplawsuits-investigations.html.

9. A. Harris, Impeachment Adds to a Long List of Trump's Legal Headaches, BloomBerG, Jan. 11, 2020, available at https://www.bloomberg.com/news/articles/2020-01-11/ impeachment-adds-to-a-long-list-of-trump-s-legal-headaches.

10. The United States Court of Appeals for the Federal Circuit upheld the decision of the Court of International Trade in a Section 232 steel case in favor of the Trump administration. American Institute for Steel v. the United States (Slip Op. 19-1727) (February 28, 2020), available at http://www.cafc.uscourts.gov/sites/default/files/ opinions-orders/19-1727.Opinion.2-28-2020_1542185.pdf The case is now headed to the Supreme Court. See generally, S. Malawer, Pending Section 232 Litigation and Broader Trade Trends: Will US Courts Restrict Presidential Authority from Relying Upon 'National Security'?, 5 China \& WTO Rev. 183 (2019); S. Malawer, Trump, Trade and National Security: Will Federal Court Rein in the President?, 5 ChInA \& WTO Rev. 417 (2019).

11. Transpacific Steel LLC v. United States, United States Court of International Trade (Slip Op. 19-1422) (Nov. 15, 2019), available at https://www.cit.uscourts.gov/sites/cit/ files/19-142.pdf.

12. Baker, supra note 8 .

13. Id.

14. A. Kumar, How Trump Fused is Business Empire to the Presidency, Politico, Jan. 20, 2020, available at https://www.politico.com/news/2020/01/20/trump-businesses-empiretied-presidency-100496.

15. B. Mastes, US Courts are a Trump Battleground, Fin. Times, Dec. 10, 2019, available at https://www.ft.com/content/788f4268-06ce-11 ea-a958-5e9b7282cbd1.

16. Id.

17. See Office of Management and Budget-Withholding of Ukraine Security Assistance, General Accounting Office B-331564 (Jan. 16, 2020), available at https://www.gao.gov/ assets/710/703909.pdf.

18. Id. at 1 .

19. J. Hilsenrah \& L. Norman, Trump Wields U.S. Economic Might in Struggles with Allies and Adversaries Alike, WALL St. J., Jan. 17, 2020, available at https://www.wsj.com/ articles/trump-wields-u-s-economic-might-in-struggles-with-allies-and-adversariesalike-11579280987 The issue of the legality of economic sanctions under international treaty law is ripe for assessment today. Especially as it relates to the validity of treaties under Article 52 of the Vienna Convention on the Law of Treaties, which declares treaties procured through the threat or use of force as void. See generally S. MALAWER, Imposed TREATies AND International LaW (1977). 
20. J. Zumbrun, Lawsuits Take on Trump's Tariff Effort, Wall St. J., Dec. 25, 2019, available at https://www.wsj.com/articles/trade-court-lawsuits-take-on-trumps-tariffcampaign-1 1577269800? $\mathrm{mod}=$ searchresults\&page $=1 \&$ pos $=1$.

21. See Publication of a Report to the President on the Effect of Automobile and AutomobilePart Imports on the National Security, U.S. Dept. of Justice Slip Opinion (Jan. 17, 2020), available at https://www.justice.gov/olc/file/1236401/download.

22. P. Krugman, Trump is Abusing His Tariff Power, Too, N. Y. Times, Jan. 23, 2020, available at https://www.nytimes.com/2020/01/23/opinion/trump-auto-tariff.html.

23. A. Gearan \& J. Hudson, Strong-Arm Tactics Remain Standard, Wash. Post, Jan. 20, 2020, available at http://thewashingtonpost.newspaperdirect.com/epaper/viewer.aspx.

24. B. Davis, U.S.-China Deal Could Upend the Way Nations Settle Disputes, Wall St. J., Jan. 16, 2020, available at https://www.wsj.com/articles/u-s-china-deal-could-upend-theway-nations-settle-disputes-11579211598.

25. Id.

26. J. McBride \& A. Chatzky, How Are Trade Disputes Resolved?, Council on Foreign Relations (Backgrounder) (Jan. 6, 2020), available at https://www.cfr.org/backgrounder/ how-are-trade-disputes-resolved.

27. J. Politi, Brussels Attacks US-China Trade Deal, Fin. TIMES, Jan. 16, 2020, available at https://www.ft.com/content/6a6b5548-3877-11ea-a6d3-9a26f8c3cba4.

28. UStR, 2019 Trade Policy Agenda and 2018 Annual Report of the President of the United States on the Trade Agreements Program 45 (2019), available at https://ustr. gov/sites/default/files/2019_Trade_Policy_Agenda_and_2018_Annual_Report.pdf.

29. See U.S. Files Appeal into System It Has Broken, Reuters, available at https://www. reuters.com/article/us-usa-trade-wto/u-s-files-appeal-into-wto-system-it-has-brokenidUSKBN1YM1XB. See also USTR, Report on the Appellate Body of the World Trade Organization (Feb. 2020), available at https://ustr.gov/sites/default/files/Report_on_the Appellate_Body_of_the_World_Trade_Organization.pdf.

30. J. Schott \& Euijin Jung, The United States Wins More WTO Cases than China in USChina Trade Disputes, Peterson Institute for International Economics (Nov. 22, 2019) (reviewing cases from 2002-2019), available at https://www.piie.com/research/piiecharts/united-states-wins-more-wto-cases-china-us-china-trade-disputes.

31. J. Schott \& Euijin Jung, In US-China Trade Disputes, the WTO Usually Sides with the United States, Peterson Institute for International Economics (Mar. 12, 2019), available at https:/www.piie.com/blogs/trade-and-investment-policy-watch/us-china-tradedisputes-wto-usually-sides-united-states.

32. S. Malawer, U.S.-China Trade Relations - Litigation in the WTO since 2001 (2001-2014), 26:2 Int'L L. Practicum 122 (Autumn 2013), available at http://globaltraderelations. net/images/Malawer.U.S._-_CHINA_LITIGATION_IN_THE_WTO_2001-2014_ NYSBA,_International_Law_Practicum_Spring_2014_.pdf. 
33. A. Gearan \& J. Hudson, Strong-Arm Tactics Remain Standard, Wash. Post, Jan. 20, 2019, available at $\mathrm{http}: / /$ thewashingtonpost.newspaperdirect.com/epaper/viewer.aspx.

34. H. Long, Trump Threatens Europe with Fresh Tariffs in Davos, Deepening the Rift with Long Time Allies, WAsh. Post, Jan. 21, 2020, available at https://www.washingtonpost. com/business/2020/01/21/trump-threatens-europe-with-fresh-tariffs-davos-deepeningrift-with-long-time-us-allies See also D. Lynch, Trump's Recent Trade Moves Show Adversarial Approach has Only Just Begun, WAsH. Post, Feb. 18, 2020, available at https://www.washingtonpost.com/business/economy/trumps-recent-trade-moves-showadversarial-approach-has-only-just-begun/2020/02/18/05772170-49ee-11 ea-b4d9$29 \mathrm{cc} 419287 \mathrm{eb}$ story.html.

35. J. Diehl, Trump's Hallmark Foreign Policy Failure? 'Maximum Pressure,' WAsh. Post, Jan. 19, 2020, available at https:/www.washingtonpost.com/opinions/global-opinions/ trumps-hallmark-foreign-policy-failure-maximum-pressure/2020/01/19/0a2ae796-387411ea-bb7b-265f4554af6d_story.html.

36. A. Flaaen \& J. Pierce, Disentangling Effects of the 2018-2019 Tariffs on a Globally Connected U.S. Manufacturing Sector, Federal Reserve Board (Dec. 23, 2019), available at https://www.federalreserve.gov/econres/feds/files/2019086pap.pdf.

37. J. Smialek \& A. Swanson, American Consumers, Not China, Are Paying for Trump's Tariffs, N. Y. Times, Jan. 6, 2020, available at https://www.nytimes.com/2020/01/06/ business/economy/trade-war-tariffs.html See also H. Long \& A. Van Dam, U.S. Manufacturing Sector Spent 2019 in a Mild Recession, Wall Sт. J., Jan. 17, 2020, available at http://thewashingtonpost.newspaperdirect.com/epaper/viewer.aspx. 
